\title{
ENTOMOLOGY
}

\section{First case of traumatic myiasis caused by Calliphora vicina in a crested porcupine Hystrix cristata L. in Italy}

\author{
D. Scaravelli, ${ }^{1}$ C. Senini, ${ }^{1}$ T. Bonacci $^{2}$ \\ ${ }^{1}$ Department of Veterinary Medical Sciences (DiMEVET), University of Bologna; ${ }^{2}$ Department of Biology, Ecology and \\ Earth Sciences (DiBEST), University of Calabria, Rende, Italy
}

\begin{abstract}
Calliphora vicina (Diptera: Calliphoridae) it is a facultative ectoparasite responsible for traumatic myiasis in humans and warmblooded vertebrates in the world. In this work one case of traumatic myasis caused by $C$. vicina (Diptera Calliphoirdae) is reported for the first time in a vulnerable crested porcupine (Hystrix cristata Linnaeus, 1758). A total of 30 larvae located in the posterior-dorsal area of the animal were removed from inside the lesion and either preserved in ethanol or reared to the adult stage. This report shows the great ability of $C$. vicina to use many organic matter for the food source's offspring, including many live vertebrates.
\end{abstract}

\section{Introduction}

Myiasis, as defined by Zumpt (1965), is an infestation of live human and vertebrate animals with dipterous larvae, which, at least for a certain period, feed on the host's dead or living tissue, liquid body-substances, or ingested food. This parasitosis can be caused by many species of Diptera, but larvae of Calliphoridae,

\footnotetext{
Correspondence: Teresa Bonacci, Department of Biology, Ecology and Earth Sciences (DiBEST), University of Calabria, via P. Bucci s.n., 87036 Rende (CS), Italy.

E-mail: teresa.bonacci@unical.it

Key words: Parasitosis; Calliphoridae; mammals, Italy.

Contributions: the authors contributed equally.

Conflict of interest: the authors declare no potential conflict of interest.

Received for publication: 29 May 2017.

Accepted for publication: 24 June 2017.

CCopyright D. Scaravelli et al., 2017

Licensee PAGEPress, Italy

Journal of Entomological and Acarological Research 2017; 49:6823 doi:10.4081/jear:2017.6823

This article is distributed under the terms of the Creative Commons Attribution Noncommercial License (by-nc 4.0) which permits any noncommercial use, distribution, and reproduction in any medium, provided the original author(s) and source are credited.
}

Sarcophagidae and Muscidae are the main responsible of traumatic myiasis in humans and animals (Zumpt, 1965; Hall \& Wall, 1995; Hall, 1997; Hall \& Farkas, 2000; Sinha, 2012). Coversely, some Muscidae are active predators of economically important pests (Bonsignore, 2016).

Calliphora vicina Robineau-Desvoidy, 1830 has an almost worldwide distribution; it mainly favours shady situations and urban habitats, where it is often the dominant species on human corpses (Smith, 1986; Bonacci, et al., 2009). Calliphora vicina it is known like facultative ectoparasites of many species of wild animals and humans (Dehlaes et al., 2001; Sales et al., 2003; Knotek et al., 2004; Salvetti et al., 2012; Araghi et al., 2015).

The crested porcupine Hystrix cristata is distributed in Northern Africa from Morocco to Northern Libya and in subSaharian Africa from Senegal to Central Tanzania (Amori et al., 2008; Mohamed, 2011); in Europe it is present only in Italian peninsula, where it shows increasing populations.

Mori et al. (2013a,b) summarized the actual distribution of the species in Italy and the steps of a wide spreading still on the move. The northern limit is represented by the province of Verona (Veneto) to the east, and by the province of Piacenza (Emilia Romagna) to the west. The Italian population of Hystrix cristata are supposed to be of archaic introduction (Trucchi \& Sbordoni, 2009; Masseti et al., 2010) probably during early Medieval times (Masseti et al., 2010).

The crested porcupine is a large rodent with sedentary habits (Amori et al., 2008). Monogamous, the members of a pair forage on the same home range and have large overlap in activity rhythms (Mori et al., 2016). This rodent is very robust, with massive short legs and a median body weight around 11-12 kg (Mori \& Lovari, 2014), powerful in defense and burrowing, but causing it to become less efficient in escape from predation (Mohr, 1965) as well as the possibility to avoid problem with vehicles when come across roads. $H$. cristata is a mainly nocturnal animal, living and breeding in burrows or dens. It is a solitary forager, known to travel long distances in search of food. The foraging behavior of the crested porcupine contributes to increase the risk of road accidents in the mosaic of agriculture and urban habitats where they are mostly distributed.

\section{Materials and methods}

A young female of around $4.5 \mathrm{~kg}$ (Figure 1) had been discov-

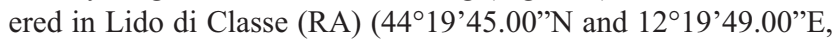
$5 \mathrm{~m}$ asl), in December 29, 2016 (December mean environmental 
$\left.\mathrm{T}=4.5 \pm 0.5^{\circ} \mathrm{C}\right)$. The specimen was very debilitated and with great difficulty to move and was brought to the Wildlife Recovery Center of the association Amici degli animali were the porcupine died in few hours.

The specimen was send to the Istituto Zooprofilattico Sperimentale of Lombardia and Emilia Romagna region for postmortem examination and the evaluation of cause of death, in a general protocol on the analysis of wildlife cases. 30 mature larvae were in total removed during the necroscopic examination, directly taken from the necrotic tissue by forceps. 15 specimens were killed by immersion for 1.5 minutes in boiling water and later fixed in $95^{\circ}$ ethyl alcohol, while the remaining third instars $(\mathrm{N}=15)$ were reared in the laboratory to the adult stage. Both the larvae and the adults were identified using the keys of Akbarzadeh et al. (2015). Digital photographs were taken with a Sony Super Steadyshot DSC-H2 digital camera. In order to define their length and age, the larvae were measured using a Veho Doscovery VMS equipped with measurement software.

\section{Results and discussion}

Young crested porcupine Hystrix cristata was found suffering for a severe fracture and decaying wound in the left side of the pelvic girdle, while a large number of maggots were feeding on the dermal and muscle necrotic tissues (Figure 2).

We examined the larvae and emerged adults comparing these with the specimens held in the collection of Forensic entomology

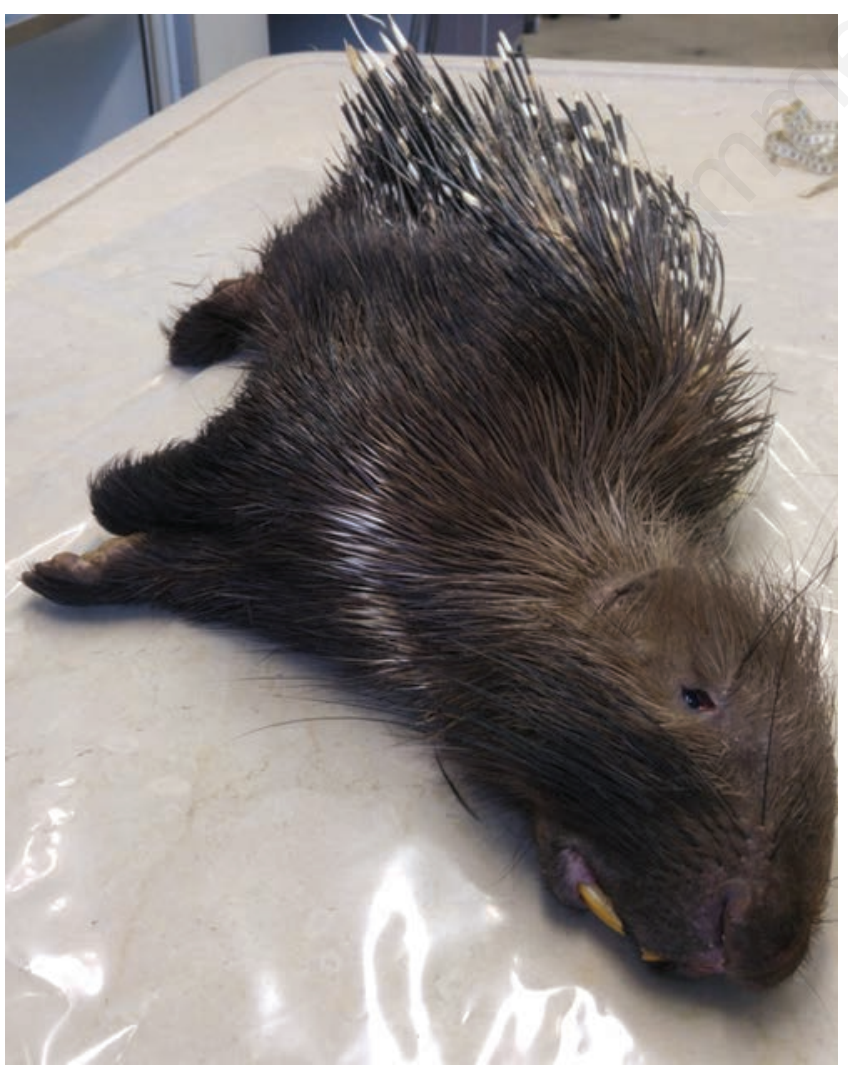

Figure 1. Young female of Crested porcupine Hystrix cristata, died few hours after the hospitalization. laboratory of DiBEST Department, University of Calabria. Both the larvae and the adults were identified as Calliphora vicina Robineau-Desvoidy, 1830 (Figure 3).

C. vicina is a cosmopolitan species known as the main forensic indicator on human corpses (Bonacci et al., 2009, 2016) and carrion (Byrd \& Castner, 2009). The species is known also as secondary myiasis agent of many wild vertebrates (Araghi et al., 2015) and with $C$. vomitoria are considered thermophobic and adapted to relatively cold and wet habitats (Davies \& Lawrence, 1992; Baz et al., 2007; Martinez-Sanchez et al., 2000; Singh \& Bharti, 2009; Martin-Vega \& Baz, 2013; Greco et al., 2014).

The data on the C. vicina life cycle show that at high temperature $\left(20-25^{\circ} \mathrm{C}\right)$ the deposited eggs have fast development as well as the entire life cycle. In this case, the presence of larvae of third age of $C$. vicina in relation to environmental temperatures $\left(\mathrm{T}_{\text {mean }}=4.5 \pm 0.5^{\circ} \mathrm{C}\right)$, suggest that the porcupine had suffered for many days. The development data of $C$. vicina in lab indicate that the species at the temperature of $5^{\circ} \mathrm{C}$ need of 8-10 days to reach the evaluated length (13.5 $\mathrm{mm}$ ) (Bonacci, unpublished data). Specifically, this timeframe is related to the colonization time by $C$. vicina. Besides, the low temperatures in December in northern Italy have prevented parasitosis by other facultative or obligate parasites.

\section{Conclusions}

In conclusion, this report shows the great ability of $C$. vicina to use many organic matter for the food source's offspring, including many live vertebrates. C. vicina it is a cosmopolitan and widespread fly species (Rognes, 1991) and as far as the risk of transmission of contamination agents, $C$. vicina ranks among the most dangerous flies ranging in Europe (Mihályi, 1967). The species contaminating the food with microorganisms present on their body surface, with their feces and regurgitated fluid. Lane \& Mader (1996) report that blowfly larvae can provoke more serious health problems in animals kept in captivity. The same authors report on the inflammatory and infection processes of injuries due to the

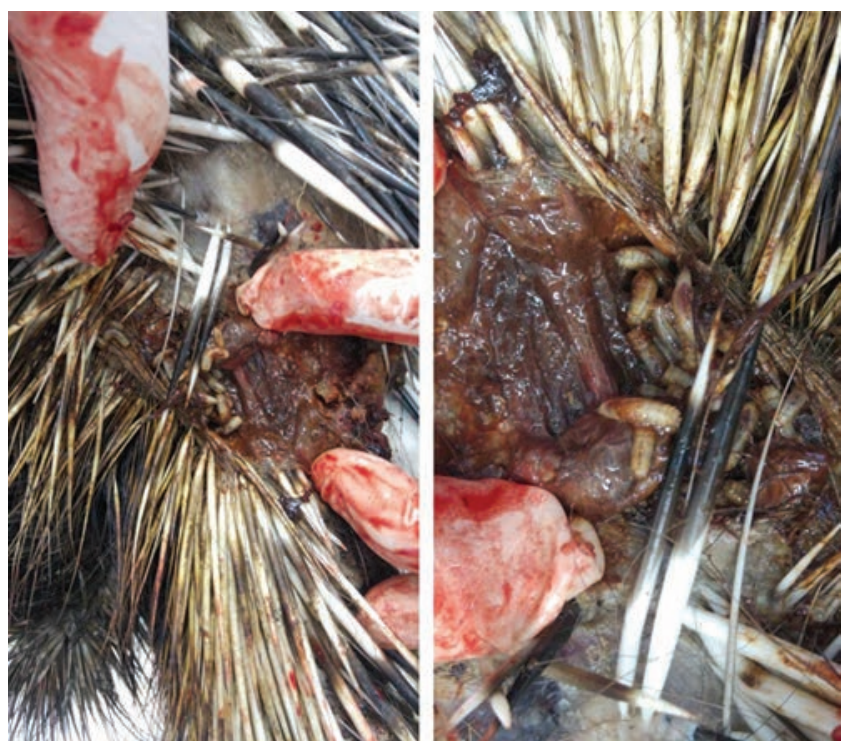

Figure 2. Calliphora vicina (Diptera, Calliphoridae) larvae inside the wound in the left side of the pelvic girdle. 

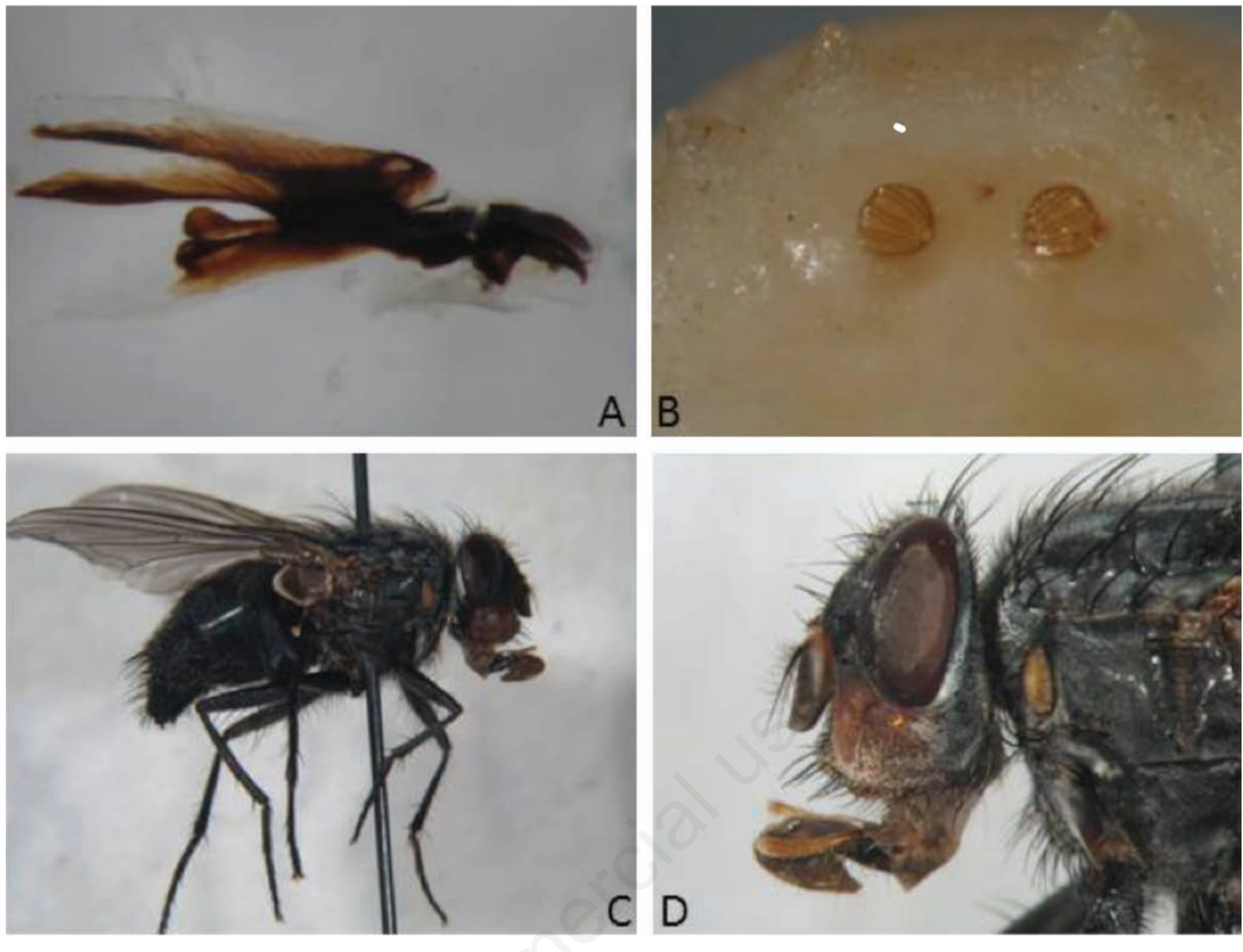

Figure 3. Calliphora vicina Robineau-Desvoidy, 1830. A) Cephalopharyngeal skeleton of third instar larva; B) Posterior spiracles of third instar larva. C) Habitus of adult (scale bar: $2 \mathrm{~mm}$ ), D) adult head, lateral view.

presence of $C$. vicina larvae and maybe also in this case the maggots may have contributed to aggravate the precarious situation of the young animal, resulted fatal as reported for other wounded animals (Knotek et al., 2004). C. vicina it is known as the main forensic indicator in the world, it causes myiasis in humans and many vertebrate species and as we reported is a facultative parasite causing traumatic myiasis in the mammal H. cristata.

\section{References}

AKBARZADEH K., WALLMAN J.A.F., SULAKOVA H.. SZPILA K., 2015 - Species identification of Middle Eastern blowflies (Diptera: Calliphoridae) of forensic importance. Parasitol. Res. 114: 1463-1472.

AMORI G., CONTOLI L., NAPPI A., 2008 - Mammalia II: Erinaceomorpha, Soricomorpha, Lagomorpha, Rodentia. Il Sole 24 Ore. Bologna: Edagricole, Calderini ed: 694-706.

ARAGHI M.P., ESKANDARI F., GILASIAN E., 2015 - Avian wound myiasis caused by Calliphora vicina RobineauDesvoidy (Diptera: Calliphoridae) in an immature migrating
Eastern Imperial Eagle (Aquila heliaca Savigny) (Aves: Accipitridae) in Southwestern Iran. - J. Vet. Sci. Technol. 6: 212. BAZ A.B., CIFRIÁN DÍAZ-ARAND L.M., MARTÍN-VEGA D., 2007 - The distribution of adult blow-flies (Diptera: Calliphoridae) along an altitudinal gradient in central Spain. Ann. Soc. Entomol. Fr. 43: 289-296.

BONACCI T., BRANDMAYR P., FONTI A., TERSARUOLO C., VERCILLO V., ZETTO BRANDMAYR T., 2009 - A case of Calliphora vicina Robineau-Desvoidy, 1830 (Diptera, Calliphoridae) breeding in a human corpse in Calabria (Southern Italy). - Leg. Med. 11: 30-32.

BONACCI T., STORINO P., SCALERCIO S., BRANDMAYR P., 2016 - Darkness as factor influencing the oviposition delay in Calliphora vicina (Diptera: Calliphoridae). - J. Forensic Leg. Med. 44: 98-102.

BONSIGNORE C.P. 2016 - Environmental factors affecting the behavior of Coenosia attenuata Stein, a predator of Trialeurodes vaporariorum (Westwood) in tomato greenhouses. - Entomol. Exp. Appl. 158: 87-96.

BYRD J.H.J., CASTNER L., 2010 - Forensic entomology. The utility of arthropods in legal investigation. - CRC Press, Boca Raton: $680 \mathrm{pp}$. 
DAVIES L., LAWRENCE B.R., 1992 - The distribution of Calliphora species in Britain and Ireland (Dipt., Calliphoridae). - Entomol. Mon. Mag. 128: 207-213.

DELHAES L., BOUREL B., SCALA L., MUANZA B., DUTOIT E., WATTEL F., GOSSET D., CAMUS D., DEI-CAS E., 2001 Recovery of Calliphora vicina first-instar larvae from a human traumatic wound associated with a progressive necrotizing, bacterial infection. - Am. J. Trop. Med. Hyg. 64: 159-161.

GRECO S., BRANDMAYR P., BONACCI T., 2014 - Synanthropy and temporal variability of Calliphoridae living in Cosenza (Calabria, Southern Italy). - J. Insect Sci. 14: 1-5.

HALL M.J.R., 1997 - Traumatic myiasis of sheep in Europe: a review. - Parassitologia 39: 409-413.

HALL M.J.R., WALL R., 1995 - Myiasis of humans and domestic animals. In: BAKER J.R., MULLER R., ROLLINSON D., eds. Advances in parasitology. - Academic Press. London: 257-334.

HALL M.J.R., FARKAS R., 2000 - Traumatic myiasis of humans and animals. In: PAPP L., B., DARVAS B., eds. Contributions to a manual of Palaearctic Diptera. Volume 1. General and applied dipterology. Science Herald. Budapest: 751-768.

KNOTEK Z., FISCHER O.A., JEKL V., KNOTKOVA Z., 2004 Fatal myiasis caused by Calliphora vicina in Hermann' tortoise (Testudo hermanni). - Acta Vet. Brno. 74: 123-128.

LANE T.J., MADER D.R., 1996 - Parasitology. In MADER D.R., ed. Reptile medicine and surgery. WB - Saunders, Philadelphia: 185-203.

MARTIN-VEGA D., BAZ A., 2013 - Sarcosaprophagous Diptera assemblages in natural habitats in central Spain: spatial and seasonal changes in composition. - Med. Vet. Entomol. 27: 64-76.

MARTINEZ-SANCHEZ A., ROJO S., MARCOS-GARCIA A., 2000 - Annual and spatial activity of dung flies and carrion in a Mediterranean holm-oak pasture ecosystem. - Med. Vet. Entomol. 14: 56-63.

MASSETI M., ALBARELLA U., DE GROSSI MAZZORIN J., 2010 - The crested porcupine, Hystrix cristata L., 1758, in Italy. - Anthropozoologica 45: 27-42.

MIHÁLYI F., 1967 - The danger-index of the synanthropic flies. Acta Zool. Acad. Sci. Hung. 13: 373-377.

MOHAMED W.F., 2011 - The crested porcupine Hystrix cristata
(Linnaeus, 1758) in Misurata, Libya. - Eur. J. Biol. Sci. 3: 9-12. MOHR E., 1965 - Altweltliche Stachelschweine. A. Ziemsen Verlag, - Wittenberg Lutherstadt: 115 pp.

MORI E., LOVARI S., 2014 - Sexual size monomorphism in the crested porcupine (Hystrix cristata). - Mamm. Biol. 79: 157-160.

MORI E., MAGGINI I., MENCHETTI M., 2013a - When quills kill: the defense strategy of the crested porcupine Hystrix cristata L., 1758. - Mammalia. 1-6.

MORI E., SFORZI A., DI FEBBRARO M., 2013b - From the Apennines to the Alps: recent range expansion of the crested porcupine Hystrix cristata L., 1758 (Mammalia: Rodentia: Hystricidae) in Italy. - Ital. J. Zool. 80: 469-480.

MORI E., MENCHETTI M., LUCHERINI M., SFORZI A. LOVARI S., 2016 - Timing of reproduction and paternal cares in the crested porcupine. . Mamm. Biol. 294: 31-40.

ROGNES K., 1991 - Blowflies (Diptera, Calliphoridae) of Fennoscandia and Denmark. - Fauna Entomologica Scandinavica. Brill, Scandinavian Science Press Ltd. Leiden.

SALES M.J., FERRER D., CASTELLÀ J., BORRÀS D., HALL M. J., 2003 - Myiasis in two Hermann's tortoises (Testudo hermanni). - Vet. Record. 153: 600-601.

SALVETTI M., CORBELLINI C., AGGIUSTI C., AGABITI ROSEI E., MUIESAN M.L., 2012 - Calliphora vicina human myiasis: a case report. - Intern. Emerg. Med. 7: S135-S137.

SINGH D., BHARTI M., 2001 - Further observations on the nocturnal oviposition behaviour of blow flies (Diptera: Calliphoridae). - Forensic Sci. Int. 120: 124-126.

SINHA S.K., 2012 - Myiasis in domestic animals: new records of calyptrate Diptera. - J. Paras. Dis. 6: 277-279.

SMITH K.G.V., 1986 - A manual of forensic entomology. British museum of natural history. Cornell University Press, London: 205 pp.

TRUCCHI E., SBORDONI V., 2009 - Unveiling an ancient biological invasion: molecular analysis of an old European alien, the crested porcupine (Hystrix cristata). - BMC Evol. Biol. 9: 109.

ZUMPT F., 1965 - Myiasis in man and animals in the Old World: a textbook for physicians, veterinarians and zoologists. Butterworth. London: 267 pp. 